
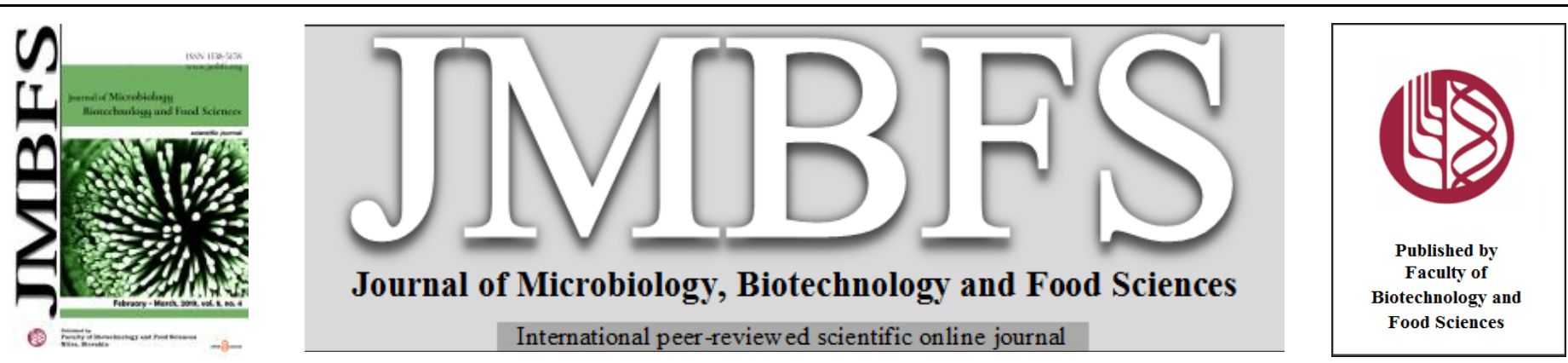

\title{
ADAPTATION OF "BIOFLOC" AQUATIC SYSTEM FOR POLYCULTURE WITH TILAPIA (OREOCHROMIS SP.) AND RIVER PRAWN (MACROBRACHIUM SP.)
}

\author{
Samira Reinoso ${ }^{*}$, Daysi Muñoz ${ }^{l}$, Ricardo Cedeño ${ }^{l}$, Juan Ortiz Tirado ${ }^{l}$, Manjunatha Bangeppagari ${ }^{1,2}$ and Sikandar I. Mulla ${ }^{3}$
}

\section{$\operatorname{Address}(e s)$ :}

${ }^{1}$ Department of Life Sciences, Laboratory of Water Resources and Aquaculture, Universidad de las Fuerzas Armadas-ESPE, Sangolquí - P.O.BOX: 171-5-231B, Ecuador, South América.

${ }^{2}$ Center for Biofluid and Biomimic Research, Pohang University of Science and Technology (POSTECH), Pohang 37673, South Korea.

${ }^{3}$ Division of Biotechnology, Chonbuk National University, Iksan 54596, Republic of Korea.

*Corresponding author: esreinos@espol.edu.ec

doi: 10.15414/jmbfs.2019.8.5.1130-1134

\section{ARTICLE INFO}

Received 15.11.2018

Revised 16. 11. 2018

Accepted 20. 11. 2018

Published 1. 4. 2019

Regular article

open $\partial$ ACCESS

\begin{abstract}
Aquaculture is a productive activity in economic growth due to market productivity which supports many Ecuadorian communities However, exotic species has been the basis of this activity without considering the endemic and mega-diverse component of Ecuador. On the other hand, current aquaculture systems use a lot of water, generating discharge of nitrogen and phosphorus, causing a negative impact on natural watersheds. The present investigation focused on the diversification of aquaculture production and environmental care, through the polyculture of tilapia and river prawn, in a Biofloc system, which allows reducing the use of water, space, and food, taking advantage of all the nutrients of the aquatic environment without generating pollutant residues, from a carbon-nitrogen ratio of 20:1. The research project was developed under laboratory conditions at 2.728 amsl, for 8 weeks in pre-breading stages. Two factors were established in the study: type of culture (monoculture and polyculture) and production systems (traditional and biofloc), with three replicates. In the Biofloc system, the environmental variables such as temperature, $\mathrm{pH}$, and oxygen did not show any significant differences between treatments $(\mathrm{p} \leq 0.05)$, while conductivity and total suspended solids increased during the test, and the nitrification processes stabilized at day 28 with values of $0.06 \pm 0.01$ and $0.35 \pm 0.09 \mathrm{ppm}$ in ammonium and nitrite respectively. The bacterial load was higher in the Biofloc system $\left(113.66 \times 10^{3} \mathrm{CFU} / \mathrm{ml}\right)$ with predominance of Bacillus sp. and Pseudomonas sp. The bioflocs showed greater volume in polyculture $(17.62 \mathrm{ml} / \mathrm{L})$ and $26 \%$ of protein. Under these considerations, the best productive performance was detected in the Biofloc polyculture with a total productivity of $142.86 \mathrm{~g} / \mathrm{m} 2(\mathrm{p} \leq 0.05)$. Therefore, diversification of species, types and culture systems are viable for aquaculture in Ecuador, generating an interaction between the chemical and biological components, allowing productive processes to be sustainable.
\end{abstract}

Keywords: Zero water exchange, intensive culture, nitrogen, polyculture, Bacillus

\section{INTRODUCTION}

Aquaculture practices in Ecuador have increased in the last decade and sustained by the production of white shrimp (Litopenaeus vannamei) and grey tilapia (Oreochromis niloticus). The estimated production for the first half of 2016 for shrimp and tilapia was 177 and 1.7 million pounds respectively according to National Aquaculture Chamber. It should be noted that the aquaculture industry of Ecuador maintains crops with one species (monoculture), constant water change, low density and constant discharges of mineral nutrients to the surrounding watersheds. This methodology generates inefficient production in established systems, increased use of antibiotics for disease control, and negative environmental impact on natural resources (Favre, 2015). In addition, the scarce diversification of species and aquaculture systems constitutes a risk to loca producers as occurred in 1999 following the crisis of the white spot disease in the Ecuadorian shrimp sector (Calderón, 2002). In this sense, diversification is an important issue that reduces risks in production, which will allow the incorporation of new systems and methodologies for the aquaculture sector, diversify risks, generate new market opportunities and increase the productivity and competitiveness of the national supply.

According to Collazos-Lasso and Arias-Castellanos (2015), protein levels of the supplied concentrate in aquaculture are usually between $20 \%$ and $45 \%$. Sixteen percent of this protein is nitrogen and about $75 \%$ of this nitrogen is added to the culture by excretion and food not consumed. The metabolism of ingested food ends with the formation of ionized and non-ionized ammonia (TAN), which is excreted into the water. The non-ionized form $\mathrm{NH}_{3}$ is highly toxic and the lethal concentration varies by species in a range of $0.001-2 \mathrm{ppm}$, in addition to generating pollution to natural watersheds. On the other hand, the aspiration of aquaculturists to achieve higher productivity without departing from environmental regulations of wastewater, biosafety, and water scarcity has led aquaculture to more intensive production systems; these systems generate greater production and less use of land and water in relation to the extensive aquaculture systems; where the recirculation of water system stands out, which has a high investment and maintenance costs; and the Biofloc system with essential aeration requirements and lower operating and investment costs (Avnimelech, 2012).

In the biofloc system, organic wastes are disintegrated and suspended inside the tanks by aeration systems, serving as a substrate for the development of heterotrophic bacteria. These bacteria are responsible for water purification, using nitrogenous compounds toxic to fish (ammonium, nitrite and nitrate), synthesizing proteins and microbial biomass that enrich the bioflocs (Kubitza, 2011). Bioflocs, as a product of a Biofloc system, are aggregates of algae, bacteria, protozoa and other organic matter, such as feces and unconsumed food; each flock remains attached to a matrix of mucus that is secreted by bacteria and bound by electrostatic attraction filamentous microorganisms to remain attached to the matrix (Hargreaves, 2013).

The present work evaluated an alternative in the intensive production of tilapia, under zero water exchange "Biofloc", incorporating a new aquaculture species such as river prawn (Macrobrachium sp.), which can be found wild in several rivers of the western Ecuadorian subtropics.

\section{MATERIALS AND METHODS}

The research was carried out on July and August of 2016 in the quarantine greenhouse of the Agricultural Engineering Career IASA1 - ESPE, located in the Rumiñahui Canton, Hacienda El Prado and province of Pichincha at 2.728 amsl. 


\section{Experimental design}

A completely random bifactorial $2 \times 3$ design was applied, the test factors being: production system (biofloc and traditional); and type of culture (polyculture prawn monoculture and tilapia monoculture). It was formed 6 treatments (Table 1) with 3 replicates and were installed 18 experimental units (EU). Each EU was a $60 \mathrm{~L}$ capacity tank, covered with plastic mesh, with heaters and aerators. In the Biofloc system was prepared a mesocosm, and the amount of water evaporated weekly was replenished; while the traditional system was maintained with a $10 \%$ water change per day.

Table 1 Detail of Biofloc treatments

\begin{tabular}{lcc}
\hline \multirow{2}{*}{ Treatments } & \multicolumn{2}{c}{ Description } \\
\cline { 2 - 3 } & Production system & Type of culture \\
\hline T1 & Biofloc & 110 river prawns $/ \mathrm{m}^{2}+100$ tilapias $/ \mathrm{m}^{3}$ \\
T2 & Traditional & 110 river prawns $/ \mathrm{m}^{2}+100$ tilapias $/ \mathrm{m}^{3}$ \\
T3 & Biofloc & 110 river prawns $/ \mathrm{m}^{2}$ \\
T4 & Traditional & 110 river prawns $/ \mathrm{m}^{2}$ \\
T5 & Biofloc & 100 tilapias $/ \mathrm{m}^{3}$ \\
T6 & Traditional & 100 tilapias $/ \mathrm{m}^{3}$ \\
\hline
\end{tabular}

\section{Biological Material}

In this study 72 tilapia $(0.44 \pm 0.03 \mathrm{~g}), 168$ river prawns $(0.29 \pm 0.01 \mathrm{~g})$, and Bacillus bacteria like probiotics were used

\section{Mesocosm formation}

A mesocosm of $500 \mathrm{~L}$ with a Carbon: Nitrogen ratio of 20:1 was created; which contained $15 \mathrm{~g}$ of fertilizer $\left(30 \% \mathrm{~N}, 10 \% \mathrm{PO}_{2}\right.$, and $\left.10 \% \mathrm{~K}_{2} \mathrm{O}\right), 200 \mathrm{~g}$ of molasses (40\% Carbon) and $125 \mathrm{~g}$ of Pond plus Bayer ${ }^{\mathbb{R}}$ probiotics; this mesocosm matured after 4 days and was the inoculum of Biofloc treatments (T1, T3, and T5). This inoculum was divided in 9 UE of Biofloc systems.

\section{Biofloc Maintenance}

A carbon-nitrogen ratio (20:1) was maintained for the formation of bioflocs and transformation of nitrogenous compounds, incorporating $2.8 \mathrm{~g}$ molasses/ $1 \mathrm{~g}$ feed balanced every 3 days according to CENIACUA (Aquaculture research Center of Colombia). Tilapia balanced feed (50\% protein) was used at the rate of $5 \%$ of the biomass distributed 3 times a day.

\section{Record of variables}

The variables measured and their frequencies were: weight of the organisms of interest, chemical parameters of the water (Biochemical oxygen demand, chemical oxygen demand, alkalinity, ammonium and nitrite), and microbiological parameters of the water (CFU and bacterial identification) every two weeks; quantity and size of the bioflocs every week; physical chemical parameters of the water (temperature, dissolved oxygen, $\mathrm{pH}$, conductivity and total solid suspended) every day; and, the proximal analysis and consumption of bioflocs at the end of the 8 weeks.

\section{Proximal analysis of bioflocs}

At the end of the experimental phase, bioflocs were lyophilized to determine the amounts of protein (Kjeldahl method (Norma INEN 543)), fat (Soxhlet method) and ash (Incinerated in muffle) (Olvera-Novoa et al., 1993).

\section{Economics Analysis}

It was performed according to the work of financial analysis in aquaculture (García, 1995), or which investment costs, operating costs and revenues were obtained, with the aim of finding significant differences between the net benefit $\left(\mathrm{USD} / \mathrm{m}^{2}\right.$ ) of each treatment.

\section{Statistical analysis}

After verification of normality and homogeneity of data, was performed a variance analysis, a Tukey test $(95 \%)$ was applied, and correlations between treatments were identified (Pearson's coefficient). For this purpose, the statistical program InfoStat ${ }^{\circledR}$ was used.

\section{RESULTS}

\section{Water Quality Variables}

The temperature was maintained with an average of $21.96{ }^{\circ} \mathrm{C}$, minimum of $18^{\circ} \mathrm{C}$ and maximum of $26{ }^{\circ} \mathrm{C}$. The $\mathrm{pH}$ showed no significant differences among production systems $(\mathrm{p}=0.4387)$ and maintained values of 7.90 to 8.60 within the acceptable range for aquaculture. Total suspended solids (TSS) showed significant differences between systems $(\mathrm{p} \leq 0.0001)$, with values higher than $200 \mathrm{ppm}$ in Biofloc treatments (Figure 1). The dissolved oxygen (DO) value maintained from 4 to $5.81 \mathrm{ppm}$, with lower values in the Biofloc treatments $(\mathrm{p} \leq 0.0001)$ (Figure 2), due to the increased oxygen consumption through respiration, oxidation and nitrification processes. Total ammoniacal nitrogen (TAN) is the most careful variable in the Biofloc system because of the toxicity and danger it represents in the aquatic environment, high levels of ammonia $(>1 \mathrm{ppm})$ are lethal to the culture organisms; in this study, nitrite and ammonium showed significant differences between treatments, with higher levels for these two variables in the Biofloc treatments (Figure 3), with mean values of $0.40 \pm 0.05$ ppm and $0.79 \pm 0.07 \mathrm{ppm}$, respectively; the amount of nitrite $\left(\mathrm{NO}_{2}\right)$ is a reflection of the nitrification processes in the Biofloc system, the increase of $\mathrm{NO}_{2}$, generally due to the decrease of ammonium, and demonstrates a correct functioning of the system, as long as these levels decrease in the weather. Alkalinity $\left(\mathrm{CaCO}_{3}\right)$ showed significant differences between treatments $(\mathrm{p}=0.0002)$, where Biofloc treatments showed the highest accumulation of $\mathrm{CaCO}_{3}(169.09 \pm 3.55 \mathrm{ppm})$ (Figure 4), these values in the Biofloc system were acceptable (100-200 ppm) allowing to maintain a constant $\mathrm{pH}$, despite variations of ammonium. The biochemical oxygen demand (BOD)/chemical oxygen demand ratio (COD), Biofloc treatments (T1, T3, and T5) showed values greater than 0.3 throughout the entire test. According to De la Torre (2009), if the ratio BOD/COD is $\geq 0.5$ the water is easily treatable or poorly contaminated, and if the ratio is $\leq 0.3$, the presence of toxic contents in the water is demonstrated. Therefore, it was worked with easily treatable, non-toxic and safe waters for aquaculture. Colony forming units (CFU), the bacterial activity is the basis of the Biofloc system, due to the nitrification processes performed by bacteria, in this study the largest number of $\mathrm{CFU}$ in the Biofloc system was found with a mean of $113.66 \pm 3.53 \times 10^{3} \mathrm{CFU} / \mathrm{m}$ $(\mathrm{p}=0.0442)$ (Figure 5), in response to the use of probiotics and the supply of molasses as energy source for bacteria. In addition, as part of the microbiologica analysis in the Biofloc system, a predominance of Bacillus $(42.40 \%)$ and Pseudomonas $(20.29 \%)$ was found; and in the traditional system Enterobacter $(47 \%)$ and Pseudomonas (41.82\%) (Figure 6).

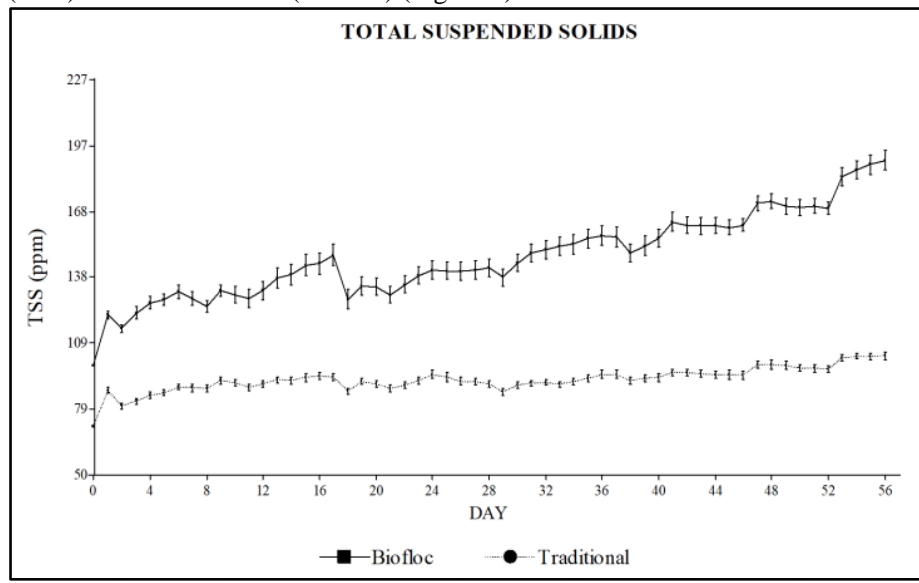

Figure 1 Mean \pm standard error of total suspended solids sampled in the 56-day experiment according to production systems.

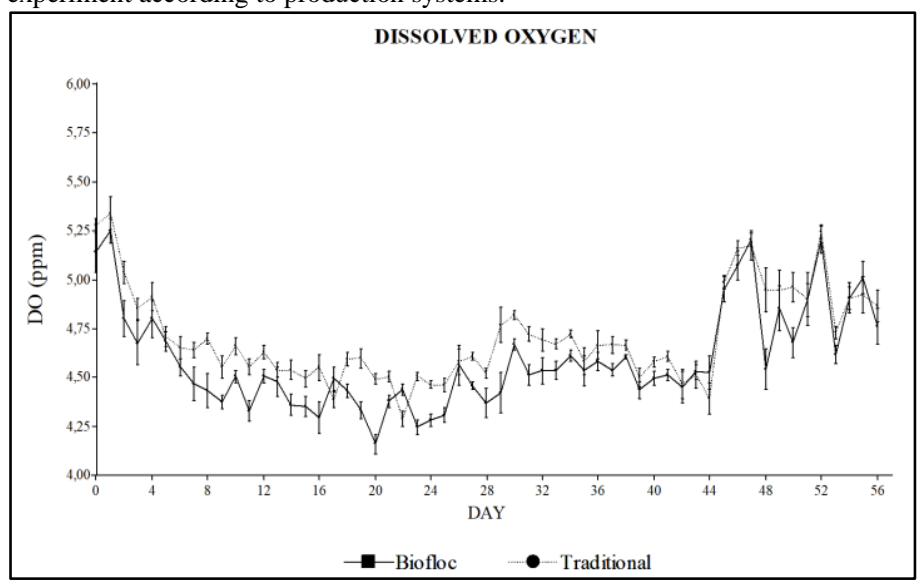

Figure 2 Mean \pm standard error of dissolved oxygen sampled in the 56-day experiment according to production systems. 


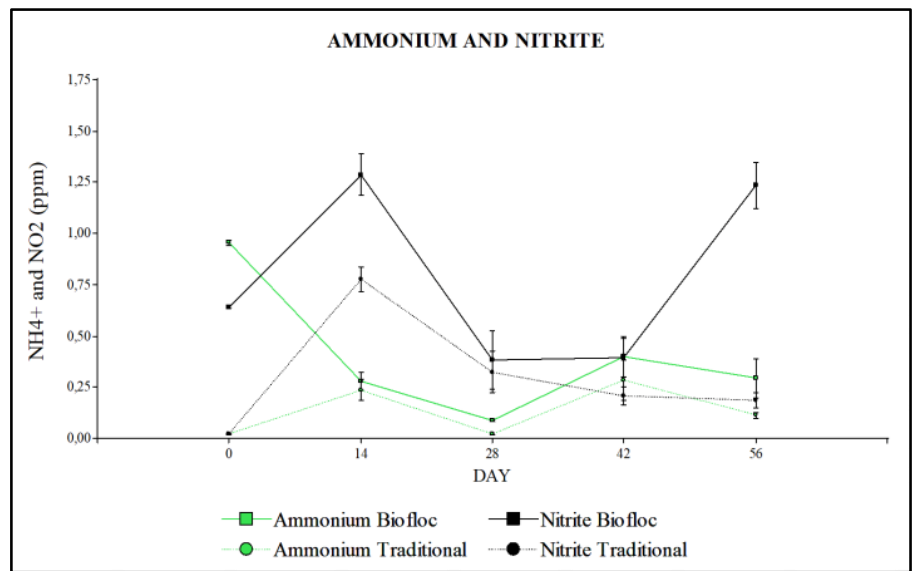

Figure 3 Mean \pm standard error of ammonical nitrogen (ammonium and nitrite) sampled in the 56-day experiment according to production systems.

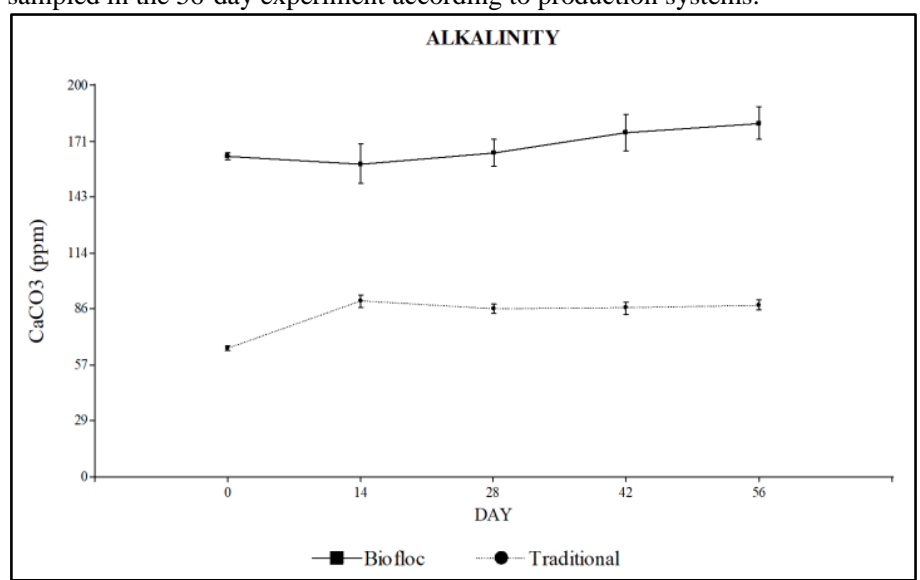

Figure 4 Mean \pm standard error of Alkalinity sampled in the 56-day experiment according to production systems.

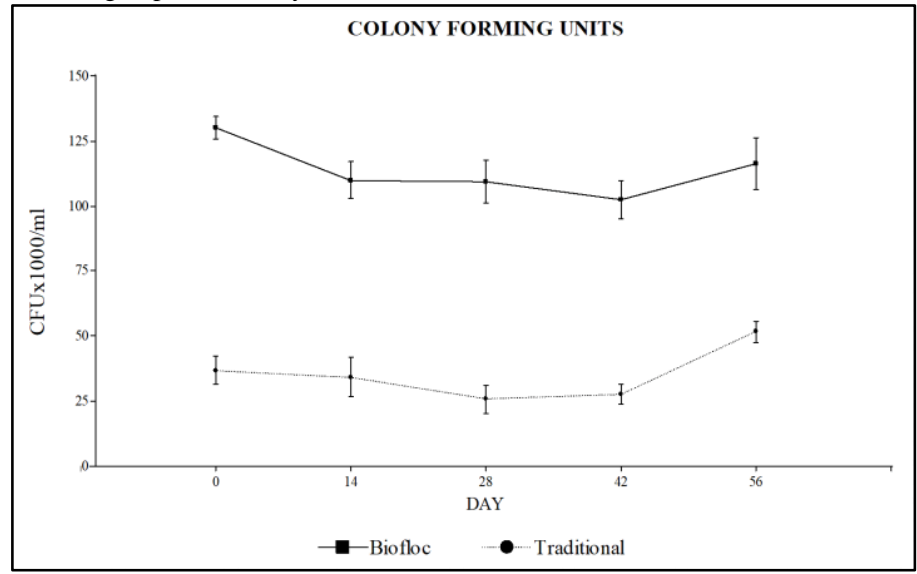

Figure 5 Mean \pm standard error of Colony Forming Units sampled in the 56-day experiment according to production systems.

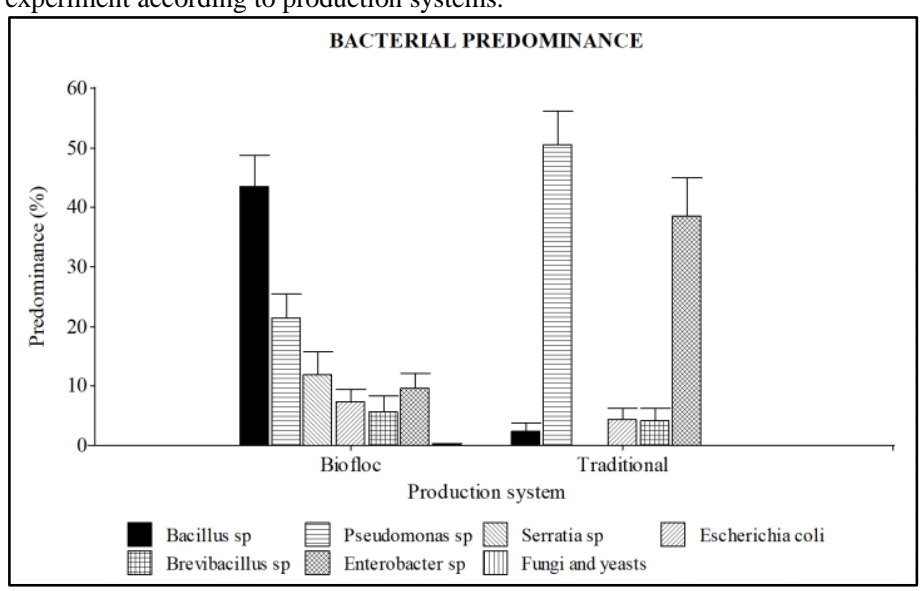

Figure 6 Bacterial predominance according to production systems and bacterial species. Based on the mean of 56-day of sampling.

\section{Production variables of Bioflocs}

The amount of bioflocs showed significant differences according to the type of culture $(p \leq 0.0001)$, sampling day $(p \leq 0001)$ and their interaction $(p=0.0362)$. Polyculture generated more flocs with an average of $17.62 \pm 1.27 \mathrm{ml} / \mathrm{L}$ (Table 2 ), given the higher animal load and dietary intake of the system. The bioflocs size generated significant differences according to the evaluation days $(p \leq 0.0001)$ reflecting an increase in size up to $3297.78 \pm 38.73 \mu \mathrm{m}$ (Table 2 ) on the last day of evaluation in all biofloc treatments. The microorganisms present in the Biofloc system were: ciliates of the genus Holosticha, Vorticella and Paramecio; rotifers of the genus Philodina; suctorias of the genus Tokophrya; amoebas of genus Euglypha; nematodes, and microalgae (Zygnema, Fragilaria, Anabaena, and Astinastrum). The microorganisms found are typical of the Biofloc system and help maintain the balance of the system and in turn enrich bioflocs. The bioflocs consumption was evident in treatments 1,3 and 5, by microscopic observation of the stomach content, where the nutritional values of flocs were $25.89 \pm 0.06 \%$ protein, $3.70 \pm 0.19 \%$ fat and $27.31 \pm 1.70 \%$ ash.

Table 2 Mean \pm standard error of Biofloc variables

\begin{tabular}{lcc}
\hline Type of culture & Amount of Biofloc $(\mathbf{m l} / \mathbf{L})$ & Biofloc size $(\boldsymbol{\mu m})$ \\
\hline Tilapia+River prawn (T1) & $17.62 \pm 1.27^{\mathrm{a}}$ & $1066.89 \pm 153.33$ \\
River prawn (T3) & $14.17 \pm 0.93^{\mathrm{b}}$ & $1115.23 \pm 176.82$ \\
Tilapia (T5) & $12.66 \pm 1.11^{\mathrm{b}}$ & $1064.45 \pm 182.19$ \\
p-value & $<0.0001$ & 0.2047 \\
\hline
\end{tabular}

Means within a row followed by different superscript are significantly different $(P \leq 0.05)$.

\section{Production variables in Tilapia}

At the end of the experimental period, weight gain was determined, with values ranging from 1.95 to $2.85 \mathrm{~g}$, without significant differences between treatments $(p=0.9861)$, however, the treatments in polyculture showed a greater weight gain $(2.85 \pm 0.28 \mathrm{~g})$. The specific growth rate: (SGR) did not show significant differences $(p=0.7785)$, however, treatment 1 and 2 showed the highest values of $3.57 \pm 0.23$ and $3.33 \pm 0.22 \%$ /day respectively. Survival did not generate significant differences, with values ranging from 75 to $83.33 \%$, however, treatment 5 (Biofloc monoculture) and 6 (Traditional monoculture) showed the highest values with $83.33 \pm 9.62 \%$ for both. The feed conversion factor (FCR) show no significant differences $(p=0.3218)$; however, T1 showed lower values of $1.28 \pm 0.03$ (Table 3)

Table 3 Mean \pm standard error of productive variables in tilapia

\begin{tabular}{lcccc}
\hline Treatments & Weight gain $(\mathbf{g})$ & $\begin{array}{c}\text { SGR } \\
(\boldsymbol{\%} / \mathbf{d a y})\end{array}$ & $\begin{array}{c}\text { Survival } \\
(\boldsymbol{\%})\end{array}$ & FCR \\
\hline 1 & $2.90 \pm 0.39$ & $3.57 \pm 0.23$ & $77.78 \pm 5.55$ & $1.28 \pm 0.03$ \\
2 & $2.80 \pm 0.49$ & $3.33 \pm 0.22$ & $72.22 \pm 5.55$ & $1.44 \pm 0.05$ \\
5 & $1.91 \pm 0.14$ & $2.83 \pm 0.31$ & $83.33 \pm 9.62$ & $1.48 \pm 0.05$ \\
6 & $1.99 \pm 0.67$ & $2.91 \pm 0.27$ & $83.33 \pm 9.62$ & $1.47 \pm 0.07$ \\
$p$-value & 0.9861 & 0.7785 & 0.7329 & 0.3218 \\
\hline
\end{tabular}

Means without superscript are no significantly different $(P \leq 0.05)$.

\section{Productive variables in river prawn}

The highest weight gain at the end of the 56 days of the evaluation was presented in T2 (traditional polyculture) with values of $380.00 \pm 37.86 \mathrm{mg}(\mathrm{p}=0.0105)$ (Table 4 ), reaching final weights of $630.00 \pm 32.15 \mathrm{mg}$. The SGR was higher for T2 with $1.53 \pm 0.10 \% \quad(p \leq 0.0001)$. Survival showed significant differences between treatments $(p=0.0014)$, where the highest survival was for T4 (traditional monoculture) with $75.00 \pm 3.57 \%$. FCR show no significant differences between treatments $(p=0.8074)$, however, T2 (traditional polyculture) showed the lowest FCR throughout the trial.

Table 4 Mean \pm standard error of productive variables in river prawn

\begin{tabular}{lcccc}
\hline Treatments & $\begin{array}{c}\text { Weight gain } \\
(\mathbf{m g})\end{array}$ & $\begin{array}{c}\text { SGR } \\
(\% / \text { day })\end{array}$ & Survival $(\%)$ & FCR \\
\hline 1 & $210.00 \pm 10.00^{\mathrm{a}}$ & $1.17 \pm 0.14^{\mathrm{ab}}$ & $21.43 \pm 0.00^{\mathrm{a}}$ & $4.31 \pm 0.37$ \\
2 & $380.00 \pm 37.86^{\mathrm{b}}$ & $1.53 \pm 0.10^{\mathrm{b}}$ & $28.57 \pm 4.12^{\mathrm{ab}}$ & $2.88 \pm 0.15$ \\
3 & $153.33 \pm 14.53^{\mathrm{a}}$ & $0.83 \pm 0.08^{\mathrm{a}}$ & $52.38 \pm 6.30^{\mathrm{bc}}$ & $5.81 \pm 0.35$ \\
4 & $213.33 \pm 48.07^{\mathrm{ab}}$ & $1.04 \pm 0.10^{\mathrm{ab}}$ & $75.00 \pm 3.57^{\mathrm{c}}$ & $4.61 \pm 0.41$ \\
$p$-value & 0.0105 & $<0.0001$ & 0.0014 & 0.8074 \\
\hline
\end{tabular}

Means within a row followed by different superscript are significantly different $(P \leq 0.05)$. 


\section{Total productivity}

The treatments that showed higher values were T1 (Biofloc polyculture) and T2 (traditional polyculture) with productivities of $142.86 \pm 24.68 \mathrm{~g} / \mathrm{m} 2$ and $133.68 \pm 17.85 \mathrm{~g} / \mathrm{m} 2$ respectively $(p=0.0020)$ (Figure 7).

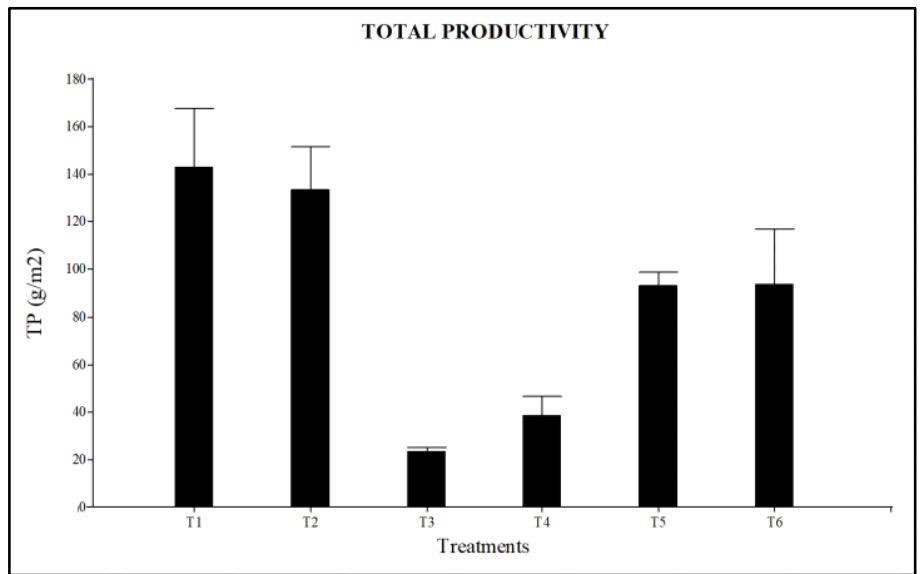

Figure 7 Mean \pm standard error of total productivity of each treatment at the end of experiment. Different letters indicate significant differences $(P \leq 0.05)$.

\section{Economic analysis}

It was determined that $\mathrm{T} 1$ (Biofloc and polyculture) obtained the greatest benefit (USD 239.06/100 $\mathrm{m}^{2}$ ). An important aspect of the economic analysis was the use of water, where the Biofloc system used the seventh part of the water in relation to the traditional system, with a water change of $10 \%$ per day.

\section{DISCUSSION}

The Biofloc treatment in polyculture represents a technological alternative that has not been implemented in Ecuador. The earlier studies refer tilapia and river prawn as complementary polyculture species (Uddin, et al., 2006). This assertion is evident in the present study, by obtaining better results in the productive variables of weight gain, SGR, and FCR in polyculture, for both river prawn and tilapia. However, polyculture survival decreases in both species, values that are rewarded by higher productivity. does not normally decrease the amount of fish produced or obstruct its growth; but the addition of fish to a shrimp system increases the total yield per pond remarkably, although could reduce the number of shrimps compared to monoculture. The above mentioned supports the results of this study, the significant increase in yield in polyculture despite to decrease in the number of prawns.

In addition, a low productive performance for Macrobrachium $\mathrm{sp}$. is demonstrated, due to the behavior and the feeding habits of this species According to New (2002), males and females have different growth rates, since males exhibit heterogeneous individual growth, where the larger male represses the growth of the smaller ones, so it is advisable to perform mono sex productions of females; Avnimelech et al., (2015) emphasized that this species requires the presence of chemo-attractants (biotin) in the food as it maintains nocturnal eating habits. Since tilapia is a species of great adaptability, it has been tested in different studies and culture conditions (Collazos-Lasso and AriasCastellanos, 2015; Kubitza, 2011), in the same way, in the present study under zero water exchange, show no significant differences in the productive variables compared to a traditional system with water exchange.

The equilibrium of the water quality variables is indispensable for the correct functioning of the Biofloc system; abrupt changes could alter the metabolism and generate mortality in the crop (Avnimelech et al., 2015). The present study does not present alterations in the physical variables of the water; however, there was a noticeable difference in the chemical variables of the Biofloc system, which are characteristic of the system.

In the Biofloc system, a large number of bacterial communities are involved in the transformation of different forms of nitrogen. In this study, bacteria such as Bacillus, Pseudomonas, and Enterobacter were found, similar to those found by Monroy-Dosta et al. (2013). No significant presence of pathogenic bacterial colonies was detected, given the dominance and probiotic action of the genus Bacillus in the Biofloc system. The consumption of bioflocs was verified as in other studies (Avnimelech et al., 2015; Browdy et al., 2012; Crab, 2010), both in tilapia and in river prawn. In addition, in the Biofloc system, bioflocs acted as a nutritional supplement for organisms of productive interest as mentioned by Avnimelech et al., (2015). This work obtained a biofloc with $26 \%$ of protein, a value within the range reported by Emerenciano et al., (2013), from 12 to $49 \%$, and comparable with a commercial fattening feed for tilapia containing $28 \%$ or finalizing food with $24 \%$ Protein of PRONACA C.A.

\section{CONCLUSION}

The productive performance shown by the polyculture tilapia and river prawn in a system of zero changes of water expressed a higher growth in the organisms, which was reflected in a greater total productivity, meeting the challenge of producing more in a smaller volume of water and at the lowest possible environmental cost. River prawn is a promising species for aquaculture, but requires further study, with special emphasis on animal load densities, nutrition, gender and age of sowing for polycultures.

The biotic and abiotic factors of the Biofloc system maintained acceptable values, which stabilized on day 28 , generating a favorable aquatic environment for the crop, allowing the development of this technology. The favorable conditions of the Biofloc system allowed to develop bioflóculos with good nutritional characteristics and to optimize the use of the water without generating any type of discharge (waste water). Based on the economic analysis, a higher net benefit was found in the Biofloc system than in mono and polyculture, due to high total productivity and efficient use of resources.

Acknowledgements: We would like to thankful to the Universidad de las Fuerzas Armadas - ESPE (IASA-I) for providing the research facilities and also thanks to Dr. Claudia Segovia and Dr. Francisco Flores (Universidad de las Fuerzas Armadas - ESPE) for the critical review of this manuscript. The coauthor (Bangeppagari Manjunatha) greatly acknowledges the Korea Research Fellowship Program through the National Research Foundation of Korea (NRF) by the Ministry of Science and ICT.

\section{CONFLICT OF INTEREST}

The authors declared that there is no conflict of interests regarding the publication of this article.

\section{REFERENCES}

AVNIMELECH, Y. (2012) Biofloc Technology, a Practical Guide Book (Second edition). Louisiana, United States. The World Aquaculture Society. ISBN: 978-1-888807-21-9.

AVNIMELECH, Y., DE-SCHRYVER, P., EMERENCIANO, M., KUHN, D., RAY, A., \& TAW, N. (2015) Microbial Processes and Communities Relevant to Aquaculture. In: Biofloc technology, a Practical Guidebook. (Third edition). Louisiana, United States. The World Aquaculture Society, pp: 21-35. ISBN 9781888807226.

BROWDY, C., RAY, A., LEFFLER, J., \& AVNIMELECH, Y. (2012) Bioflocbased Aquaculture Systems. In: Tidwell J. (Ed.) Aquaculture Production Systems $\begin{array}{llll}\text { (First ed). } & \text { Wiley-Blackwell, } & \text { pp: }\end{array}$ https://doi.org/10.1002/9781118250105.ch12

CALDERÓN J. (2002) Analysis of a traumatic experience: The WSSV in Ecuador. The Aquaculture World. 8:1, pp: 20-24. Available from: http://www.dspace.espol.edu.ec/handle/123456789/8738

COLLAZOS-LASSO, L. F., \& ARIAS-CASTELLANOS, J. A. (2015) Fundamentals of bioflocs technology (BFT). An alternative for fish farming in Colombia. A review. Orinoquia, 19:1, pp. 77-86. https://doi.org/10.22579/20112629.341

CRAB, R. (2010) Bio-flocs technology: an integrated system for the removal of nutrients and simultaneous production of feed in aquaculture. $\mathrm{PhD}$ thesis, Ghent University, Belgium. ISBN: 978-90-5989-395-5. Available from: http://hdl.handle.net/1854/LU-1043318

DE LA TORRE, E. (2009) Water quality index. Quito, Ecuador. Water Pollution and its Control.

EMERENCIANO, M., G. GAXIOLA, AND G. CUZON. (2013) Biofloc Technology (BFT): A review for aquaculture application and animal food industry. In: Miodrag D. (Ed.), Biomass Now - Cultivation and Utilization. InTech, pp: 321-328. http://dx.doi.org/10.5772/53902.

FAVRE, J. L. (2015) Technology zero water exchange, IV AQUACULTURE NATIONAL CONGRESS. Huaura, Perú, 12-16. October 2015. Acuahuaura Available from: https://es.scribd.com/document/354309348/tecnologia-cerorecambio-pdf

GARCÍA, I. (1995) Methodological aspects for financial analysis in fish farming. Universidad de Córdoba. 8, pp: 53-67.

HARGREAVES, J. (2013) Biofloc Production Systems for Aquaculture. Southern Regional Aquaculture Center. $\mathrm{N}^{\circ} 4503$, pp: 1-12. Available from https://aquaculture.ca.uky.edu/sites/aquaculture.ca.uky.edu/files/srac 4503 biofl oc_production_systems_for_aquaculture.pdf

KUBITZA, F. (2011) Cultivation of tilapias in a system with bioflocs withou water renewal. Aquaculture panorama, 21:125, pp:14-23. Available from https://www.agroindustria.gob.ar/sitio/areas/acuicultura/publicaciones/ archivos/ /000000_Desarrollos\%20Acu\%C3\%ADcolas/130808_Cultivo\%20de\%20tilapias \%20en\%20sistemas\%20con\%20bioflocos.pdf

MONROY-DOSTA, M. D. C., LARA-ANDRADE, D., CASTRO-MEJÍA, J., CASTRO-MEJÍA, G., \& COELHO-EMERENCIANO, M. G. (2013) Microbiology community composition and abundance associated to biofloc in 
tilapia aquaculture. Journal of marine biology and oceanography, 48:3, pp: 511520. ISSN 0718-1957. http://dx.doi.org/10.4067/S0718-19572013000300009

NEW, M. B. (2002) Farming freshwater prawns: A manual for the culture of the giant river prawn (Macrobrachium rosenbergii). Rome, Italy. Food and Agriculture Organization of the United Nations. ISBN: 92-5-104811-8. https://doi.org/10.1016/j.aquaculture.2003.08.004

OLVERA-NOVOA, M. A., MARTÍNEZ PALACIOS, C. A., \& REAL DE

LEÓN, E. (1993) Technical Manual for Nutrition Laboratory: Fish and Crustaceans. México, D.F. Food and Agriculture Organization of the United Nations. Available from: http://www.fao.org/docrep/field/003/ab479e/AB479E00.htm

UDDIN, S., EKRAM-UL-AZIM, M., WAHAB, A., \& VERDEGEM, M. C.

(2006) The potential of mixed culture of genetically improved farmed tilapia (Oreochromis niloticus) and freshwater giant prawn (Macrobrachium rosenbergii) in periphyton-based systems. Aquaculture Research, 37:3, pp: 241247. https://doi.org/10.1111/j.1365-2109.2005.01424.x 